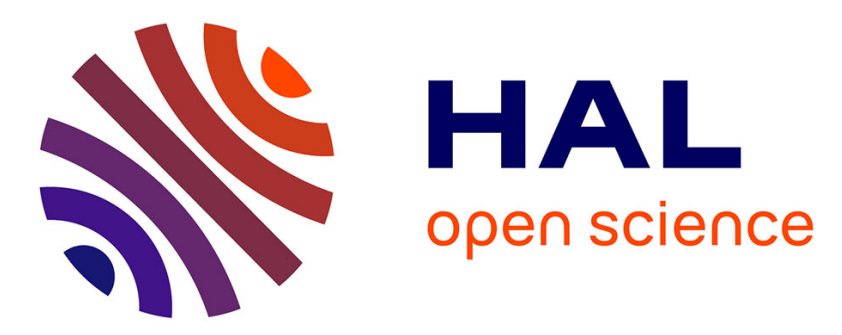

\title{
Increased gelling agent concentration promotes somatic embryo maturation in hybrid larch (Larix x eurolepsis): a 2-DE proteomic analysis
}

Caroline Teyssier, Cécile Grondin, Ludovic Bonhomme, Anne-Marie Lomenech, Michel Vallance, Domenico D. Morabito, Philippe Label, Marie-Anne Lelu-Walter

\section{To cite this version:}

Caroline Teyssier, Cécile Grondin, Ludovic Bonhomme, Anne-Marie Lomenech, Michel Vallance, et al.. Increased gelling agent concentration promotes somatic embryo maturation in hybrid larch (Larix x eurolepsis): a 2-DE proteomic analysis. Physiologia Plantarum, 2011, 141 (2), pp.152-165. 10.1111/j.1399-3054.2010.01423.x . hal-02648615

\section{HAL Id: hal-02648615 https://hal.inrae.fr/hal-02648615}

Submitted on 29 May 2020

HAL is a multi-disciplinary open access archive for the deposit and dissemination of scientific research documents, whether they are published or not. The documents may come from teaching and research institutions in France or abroad, or from public or private research centers.
L'archive ouverte pluridisciplinaire HAL, est destinée au dépôt et à la diffusion de documents scientifiques de niveau recherche, publiés ou non, émanant des établissements d'enseignement et de recherche français ou étrangers, des laboratoires publics ou privés. 


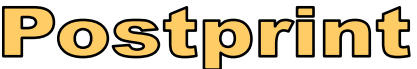

Version définitive du manuscrit publié dans / Final version of the manuscript

published in : Physiologia Plantarum. 2010, 141(2), 152-165

\section{Increased gelling agent concentration promotes somatic embryo maturation in hybrid larch}

(Larix $x$ eurolepsis): a 2-DE proteomic analysis.

Caroline Teyssier ${ }^{*}$, Cécile Grondin ${ }^{1}$, Ludovic Bonhomme ${ }^{2}$, Anne-Marie Lomenech ${ }^{3}$, Michel Vallance $^{1}$, Domenico Morabito ${ }^{4}$, Philippe Label ${ }^{1 \text { \# }}$, Marie-Anne Lelu-Walter ${ }^{1 \#}$

1: INRA, UR 588, Research Unit for Breeding, Genetics and Physiology of Forest trees, 2163 Avenue de la Pomme de Pin CS 4001, Ardon, F-45075 Orléans Cedex 2, France

2: INRA, UMR de Génétique Végétale, INRA-CNRS- Univ Paris Sud-AgroParisTech, Ferme du Moulon,F-91190 Gif-sur-Yvette, France.

3: INRA-University of Bordeaux, UMR BIOGECO, 69 route d'Arcachon, F33612 Cestas, France.

4: University of Orléans, LBLGC, USC ARCHE, rue de Chartres, BP 6759, F45067 Orléans Cedex 2, France.

*: corresponding author, fax.(+33)238417879, e-mail. teyssier@orleans.inra.fr

\#: both authors contributed equally 


\begin{abstract}
An integrated physiological and proteomic approach was used to investigate the effects of high gellan gum concentration in the medium during maturation of somatic embryos of hybrid larch, by comparing embryos incubated in media with a high gellan gum concentration $\left(8 \mathrm{gL}^{-1}\right)$ and the conventional concentration $\left(4 \mathrm{gL}^{-1}\right)$ after $1,3,6$ and 8 weeks of maturation. Due to the reduced availability of water in the $8 \mathrm{gL}^{-1}$ medium, the embryos cultivated on it had lower osmotic potential and water contents, but higher dry weights, at 8 weeks than embryos cultivated on the standard medium. The high gellan gum concentration induced a desiccation as occurring during zygotic embryo maturation. Total soluble proteins were extracted from embryos with TCA-acetone after 1 and 8 weeks of maturation on media with 4 and $8 \mathrm{gL}^{-1}$ of gellan gum, and separated by two-dimensional gel electrophoresis at $\mathrm{pH} 4-7$. More than 1100 proteins were reproducibly detected on each gel. At 1 and 8 weeks respectively, the abundances of 62 and 49 spots detected in analyses of embryos matured at the two gellan gum concentrations significantly differed. Among 62 significantly differing spots at 1 week of maturation, the corresponding proteins of 56 were reliably identified by LC-MS/MS, and were found to be mainly involved in "Carbohydrate metabolism", "Genetic information processing" or "Environmental information processing" according to KEGG taxonomy. Both physiological parameters and the proteins identified suggested that the embryos were stressed when they were cultivated on $4 \mathrm{gL}^{-1}$ of gellan gum.
\end{abstract}

\begin{abstract}
Abbreviation:
ABA, abscisic acid; EMs, embryonal masses; DW, dry weight; FW, fresh weight; SE, somatic embryos
\end{abstract}

\title{
Introduction:
}

Advances in biotechnology offer attractive new opportunities for propagating conifers. Clonal propagation methods, such as somatic embryogenesis, have potentially numerous applications and advantages over conventional rooted cuttings (Klimaszewska et al. 2007). The speed with which new material can be produced and the high potential for clonal multiplication make somatic embryogenesis a powerful and flexible tool for the release of improved varieties. Since the 1990s, INRA has carried out research on somatic embryogenesis in larch species, particularly hybrid larch Larix x eurolepis (L. decidua $\mathrm{x}$ L. kaempferi) which is known for its remarkable vigour, together with superior stem straightness and adaptation to a range of sites, compared to the parental species (Pâques 1992).

The most critical step in the production of high quality somatic embryos is the conversion of embryos to plants. Somatic embryo maturation is a complex process that is influenced by many factors. Hence, to optimise maturation in order to exploit the embryogenic potential of various hybrid lines as fully as possible it is necessary to consider and optimise all of these factors. Key factors include the plant 
hormone ABA and the osmotic potential of the medium. Hence, culture media with high abscisic acid (ABA) and sucrose contents have been routinely used to promote somatic embryo maturation in larch and spruce species (Lelu and Label 1994, Attree et al. 1995). In addition, partial or full desiccation treatments applied to somatic embryos promote plantlet development (Lelu et al. 1995), and most seeds become desiccated during the latter stages of zygotic embryo development; a process that plays an important role in the transition between embryo maturation and germination (Kermode 1990). Furthermore, somatic embryos subjected to desiccation for a week reportedly showed transient increases in their endogenous ABA contents, within 6 to 24 hours (Dronne et al. 1997). Thus, somatic embryos appear to be capable of adapting and responding very rapidly to environmental changes.

The maturation of somatic embryos of various pine species is routinely promoted by using media with very high gellan gum concentrations (up to $12 \mathrm{gL}^{-1}$, as reviewed by Klimaszewska et al. 2007). This effect was also recently observed in hybrid larch, for which an increase in gel strength from $4 \mathrm{gL}^{-1}$ to 8 $\mathrm{gL}^{-1}$ greatly enhanced recovery of well-shaped cotyledonary somatic embryos that were able to germinate and develop into plantlets at a high rate (Lelu-Walter and Pâques 2009). It has been demonstrated that increasing gel strength results in a reduction in availability of water for the cultured cells (Klimaszewska et al. 2000), a critical factor for pine somatic embryo maturation. Osmotic conditions also appear to control seed development in vivo (reviewed in Bradford 1994), yet few osmotic measurements have been obtained for conifer somatic embryos (Klimaszewska et al. 2000). Therefore, the first objective of this study was to characterize the osmotic potential and water content of hybrid larch somatic embryos during maturation on media of different gellan gum concentrations.

In hybrid larch, efforts have been made to describe somatic embryo maturation at the molecular level (Mathieu et al. 2006, Guillaumot et al. 2008). As a further and complementary step to gene expression analyses, studies at the proteomic level may also help to develop new in vitro culture strategies for plant propagation by identifying protein markers of optimal or stressed culture conditions. Qualitative or semi-quantitative techniques have been use to characterise the protein contents during maturation of somatic embryos of hybrid larch (Gutmann et al. 1996) and several other conifer species, such as spruce (Hakman et al. 1990, Roberts et al. 1990), and pines (Klimaszewska et al. 2004, Lelu-Walter et al. 2006). However, two-dimensional gel electrophoresis (2-DE; a powerful tool for the separation, simultaneous display and quantification of large numbers of proteins) has only been applied, in conifer somatic embryology studies, to examine changes in protein profiles during the regular development of somatic embryos of Picea abies (Hakman et al. 1990), Cupressus sempervirens (Sallandrouze et al. 1999) and Picea glauca (Lippert et al. 2005). There have been no previously published attempts to examine and compare protein profiles during the maturation of somatic embryos, of any conifer species, under more than one set of experimental conditions.

The second objective was to identify proteins that are differentially regulated during embryo maturation in the presence of high $\left(8 \mathrm{gL}^{-1}\right)$ or low concentrations $\left(4 \mathrm{gL}^{-1}\right)$ of gellan gum. Since somatic 
embryos subjected to drying treatment may rapidly react to environmental change (Dronne et al. 1997), this study was conducted after one week of maturation. The 2-DE patterns obtained under the two experimental conditions were compared, and proteins displaying consistent variation between the conditions were identified by means of tandem mass spectrometry.

We report here results that describe for the first time a 2-DE proteomic analysis of the maturation of conifer somatic embryos on media with different gelling agent concentrations. The protein expression profiles provide novel insights into the process of somatic embryo maturation in hybrid larch, and a basis for practical application of this knowledge.

\section{Material and methods}

\section{Culture of embryonal masses:}

Experiments were conducted with the N23 line of hybrid larch Larix x eurolepis (L. decidua x L. kaempferi) obtained in 2003 at INRA Orléans, France, from an immature zygotic embryo (LeluWalter and Pâques 2009). Embryonal masses (EMs) were subcultured in clumps every two weeks onto fresh proliferation medium, which consisted of basal MSG medium supplemented with $9 \mu \mathrm{M} 2,4-$ dichlorophenoxyacetic acid, $2.3 \mu \mathrm{M}$ 6-benzyladenine and $60 \mathrm{mM}$ sucrose, solidified with $4 \mathrm{gL}^{-1}$ gellan gum (Becwar et al. 1990). EMs were multiplied according to the proliferation method previously developed for pine species (Lelu-Walter et al. 2006, Lelu-Walter et al. 2008). One-week-old proliferating EMs were collected and suspended in $5 \mathrm{ml}$ of liquid proliferation medium, vigorously shaken to break them up into a fine suspension, and poured as a thin layer onto a filter paper (Whatman $\mathrm{N}^{\circ}$ 2) in a Büchner funnel. A low-pressure pulse was applied to drain the liquid, and the filter paper with attached cells was placed on the surface of fresh proliferation medium. The density of EMs was approximately $300 \mathrm{mg}$ fresh weight $(\mathrm{FW})$ per filter. Maturation of the somatic embryos (SE) was carried out according to Lelu and Pâques (2009). Briefly, one-week-old EMs actively growing on filter paper were weighed, dispersed into liquid MSG medium with no plant growth regulator (PGR), and distributed onto a filter paper disc as previously described for the proliferation step. Filter paper discs with dissociated EMs (approximately $200 \mathrm{mg}$ fresh mass) were incubated for one week on PGRfree MSG medium supplemented with activated charcoal $\left(10 \mathrm{gL}^{-1}\right), 0.1 \mathrm{M}$ sucrose and $4 \mathrm{gL}^{-1}$ gellan gum. Filters were then transferred onto MSG basal medium containing $0.2 \mathrm{M}$ sucrose, $1 \mu \mathrm{M}$ indolebutyric acid, $60 \mu \mathrm{M}$ cis-trans ( \pm )-abscisic acid (ABA) and either $4 \mathrm{gL}^{-1}$ or $8 \mathrm{gL}^{-1}$ gellan gum. Maturation was conducted in darkness. After transfer onto the ABA maturation media, somatic embryos (SEs) underwent maturation. During early stages, after 1, 3 and 6 weeks (von Aderkas et al. 2001), SEs were too small to be collected without surrounding suspensor parts, but after 8 weeks they were already cotyledonary and easily isolated from the rest of the culture. Biological replicates were 
obtained by harvesting embryos from different Petri dishes containing material at the same maturation stage.

Harvested SEs were directly frozen in liquid nitrogen and stored at $-80^{\circ} \mathrm{C}$ until required for osmotic potential measurement and proteomic analysis. The samples destined for water content determinations were used immediately after the harvest.

\section{Dry weight and water content of the samples:}

At each collection date, the samples (about $200 \mathrm{mg}$ ) were weighed immediately after harvest to determine their FW, and their dry weight (DW) was determined after oven-drying at $70^{\circ} \mathrm{C}$ for $6 \mathrm{~h}$. Their percentage dry weight was calculated by multiplying their dry weight to fresh weight ratio by 100, and their water content, expressed as $\mathrm{g}_{2} \mathrm{O} / \mathrm{g}$ DW (Dronne et al., 1997), was calculated as follows: water content $=(\mathrm{FW}-\mathrm{DW}) / \mathrm{DW}$. Nine samples were assayed for each developmental stage.

\section{Water availability:}

Water availability of the maturation medium was determined from the water content of the paper filter after incubation on the medium, as previously described (Klimaszewska et al. 2000). An autoclaved filter paper disc (Whatman $\mathrm{N}^{\circ} 2$ ) was placed on the medium with 4 or $8 \mathrm{gL}^{-1}$ gellan gum. The Petri dish was sealed with Parafilm and incubated for $48 \mathrm{~h}$ under the same conditions as for the maturation of EMs. The filter paper disc was subsequently weighed, and its dry weight was obtained after ovendrying at $40^{\circ} \mathrm{C}$ for 2 hours. The amount of water absorbed by the paper disc was normalised by the ratio between the mean weight of 10 filter paper discs and the weight of the individual paper disc. The assay was repeated with five filter paper discs per medium with no culture on it, to determine the initial water availability.

\section{Osmotic potential:}

The osmotic potential of samples of somatic embryos harvested at each collection date was determined as follows. The samples (200 mg FW) were ground using a pestle directly in the tube and centrifuged for $2 \mathrm{~min}$ at $13000 \mathrm{~g}$, then the osmotic potential of $100 \mu \mathrm{l}$ of the supernatant was measured using a Hermann Roebling type 13/13 DR automatic pressure micro-osmometer (Messtechnik, Berlin, Germany). Values in osmolarity units (mosmol/kg water) were converted to MPa using the Van't Hoff equation, $\pi=$-CiRT: where $\mathrm{C}$ is the osmolarity value in $\mathrm{mol} / \mathrm{kg}$, $\mathrm{i}$ is an ionization constant assumed to be equal to unity, $\mathrm{R}$ is the gas constant $(0.00831 \mathrm{~kg} \cdot \mathrm{MPa} / \mathrm{mol} / \mathrm{K})$, and $\mathrm{T}$ is absolute temperature (in Kelvin). The osmotic potential of the maturation media, and (as negative controls) maturation media maintained under the same conditions without any culture, was also measured. The assay was repeated 10 times for each sample type (embryos or media with either 4 or $8 \mathrm{gL}^{-1}$ of gellan gum). 


\section{Protein extraction for 2D gels:}

Frozen sample (400 mg) of each type to be analysed was placed in a pre-chilled mortar, and ground in liquid $\mathrm{N}_{2}$ for $5 \mathrm{~min}$ to a fine powder. The frozen powder was transferred to a $2 \mathrm{ml}$ microtube and proteins were extracted with TCA-acetone precipitation as described in Damerval et al (1986). Briefly, the powder was homogenized in $1.8 \mathrm{ml}$ of precipitation solution $(10 \%(\mathrm{w} / \mathrm{v}) \mathrm{TCA}, 0.07 \%(\mathrm{v} / \mathrm{v}) \beta-$ mercaptoethanol in cold acetone), and proteins were allowed to precipitate for 2 hours at $-20^{\circ} \mathrm{C}$. The mixture was then centrifuged and the resulting pellet was washed three times with $0.07 \%(\mathrm{v} / \mathrm{v}) \beta$ mercaptoethanol in cold acetone (centrifuging each time at $14000 \mathrm{~g}$ for $15 \mathrm{~min}$ at $4^{\circ} \mathrm{C}$ ). The extract was completely dried before resolubilisation in $7 \mathrm{M}$ urea, $0.4 \%(\mathrm{v} / \mathrm{v})$ Triton ${ }^{\circledR X} 100,4 \%(\mathrm{w} / \mathrm{v})$ CHAPS, $2 \mathrm{M}$ thiourea, $10 \mathrm{mM}$ DL-dithiothreitol and $1 \%(\mathrm{v} / \mathrm{v})$ IPG buffer. The protein concentration in each preparation was determined using a modified Bradford assay described by Ramagli and Rodriguez (1985) with Bovine Serum Albumin as a standard.

\section{2-D PAGE analyses:}

For the first dimension separation, samples prepared as described above containing $300 \mu \mathrm{g}$ protein were loaded onto 24-cm IPG strips, pH 4-7 (Protean IEF Cell system, Biorad, France) and subjected to isoelectric focusing (IEF) at $25^{\circ} \mathrm{C}$ for $60 \mathrm{kVh}$ using an IPGphor system (GE healthcare Europe, France). Prior to the second dimension separation, strips were equilibrated twice for $10 \mathrm{~min}$ under gentle shaking at room temperature in equilibration solution $(50 \mathrm{mM}$ Tris $\mathrm{HCl} \mathrm{pH} 8.8 ; 6 \mathrm{M}$ urea; 30\% $(\mathrm{v} / \mathrm{v})$ glycerol; $2 \%(\mathrm{v} / \mathrm{v})$ SDS; $0.002 \%(\mathrm{w} / \mathrm{v})$ BBP) containing $1 \%(\mathrm{w} / \mathrm{v})$ DL-dithithreitol and 2.5\% (w/v) iodoacetamide, respectively. Then 2-D PAGE was performed using an Ettan Dalt six unit (GE, France) with $11 \%$ polyacrylamide gels, overnight at constant $110 \mathrm{~V}$ and $80 \mathrm{~mA}$. Four biological replicates were analysed for each sample. Gels were stained with colloidal CBB-G according to Gion et al. (2005), then images were captured with a transmission densitometer (ImageScanner, GE Healthcare, France) at 600-dpi resolution, digitized and analysed using Progenesis software (Nonlinear Dynamics, United Kingdom). The volume of each spot detected was normalised relative to the total volume of the spots on the gel. Every spot detected automatically was manually checked.

\section{Nanospray LC-MS/MS and data analysis:}

In-gel digests of the excised spots were carried out using trypsin according to the procedure described by Plomion et al. (2006). Peptides were analyzed by on-line capillary HPLC coupled to a nanospray LCQ Deca XP Ion Trap mass spectrometer (Thermo-Finnigan, San Jose, CA). The peptides were eluted from the trap column onto an analytical $75-\mu \mathrm{m}$ id $\mathrm{x} 15-\mathrm{cm}$ C18 PepMap ${ }^{\mathrm{TM}}$ column (LC Packings) with a 5-40\% linear gradient of solvent B over 35 min (where solvent A was $0.1 \%$ formic acid in 5\% ACN, and solvent B was $0.1 \%$ formic acid in $80 \% \mathrm{ACN}$ ). The separation flow rate was set at $200 \mathrm{nl} / \mathrm{min}$. The mass spectrometer was operated in positive ion mode with a $2-\mathrm{kV}$ needle voltage and a $3-\mathrm{V}$ capillary voltage. Data were acquired in a data-dependent mode alternating between a MS 
scan survey over the range $\mathrm{m} / \mathrm{z} 150-2000$, a zoom scan on the most intense ion and its MS/MS spectrum using a $2 \mathrm{~m} / \mathrm{z}$ units ion isolation window and a $35 \%$ relative collision energy. After mass spectrometric analyses, all data were searched using the SEQUEST algorithm through the Bioworks 3.3.1 interface (ThermoFinnigan) against 355,326 entries in the DFCI Pine Gene Index release 7.0 (http://compbio.dfci.harvard.edu/tgi/cgi-bin/tgi/gimain.pl?gudb=pine; July 2008). DTA files were generated for MS/MS spectra that reached both a minimal intensity $\left(5.10^{-4}\right)$ and a sufficient number of ions (15). The DTA generation allowed the averaging of several MS/MS spectra corresponding to the same precursor ion with a tolerance of $1.4 \mathrm{Da}$. Spectra from precursor ions with molecular masses higher than $3500 \mathrm{Da}$ or lower than $600 \mathrm{Da}$ were rejected. The search parameters were as follows: mass accuracy for the peptide precursor and peptide fragments was set to $2 \mathrm{Da}$ and $1 \mathrm{Da}$, respectively. Only b- and y-ions were considered for mass calculation. Oxidations of methionines (+ $16 \mathrm{Da})$ and carbamidomethylation of cysteines $(+57 \mathrm{Da})$ were considered as differential modifications. Two missed trypsin cleavages were allowed. Only peptides with Xcorr higher than 1.9 (single charge), 2.2 (double charge) and 3.75 (triple charge) were retained. In all cases, $\Delta \mathrm{Cn}$ had to be higher than 0.1 and the peptide $\mathrm{p}$-value lower than $10^{-3}$. Proteins identified by a unique peptide were rejected. Proteins were classified into groups based on their functional categories using the KEGG orthology database (http://www.genome.jp/kegg/kegg2.html).

\section{$\underline{\text { Statistical analyses: }}$}

Statistical analysis was carried out with R software (version 2.8.0; R Development Core Team, 2008. $\mathrm{R}$ : A language and environment for statistical computing. R Foundation for Statistical Computing; Vienna, AU). Effects of the treatments on the dry weight, water content and osmotic potential measurements were evaluated using one-way ANOVA. Variations of these parameters during maturation in relation to the gellan gum level in the medium were analysed with multiple comparisons of means with Tukey contrasts $(p<0.001$ or $p<0.05)$. The effects of gellan gum on osmotic potential at the 8-week stage were evaluated by Student's $t$-test.

The pattern of each spot in the proteomic study was analysed by Student's $t$-test on the basis of the normalised spot volume $(p<0.05)$. Any spot with a $p$-value of $<0.05$ according to Students' $t$-test associated with the gellan gum treatment was deemed to have changed significantly between treatments and was subsequently excised. Sixty-two spots were identified for excision by this process.

\section{Results}

\section{$\underline{\text { Water status of SE cultures }}$}

To characterize the water status of the SE cultures during their maturation, the water content and dry weight of the embryos on both types of media were followed throughout their development (Fig. $1 \mathrm{~A}$ 
and B). Compared to embryos cultivated on medium with $4 \mathrm{gL}^{-1}$ gellan gum, embryos transferred to medium with $8 \mathrm{gL}^{-1}$ gum showed a significant increase in DW $(p<0.007$, Fig. 1A) and reduced water content ( $p<0.007$, Fig. 1B). In addition, the two parameters, DW and water content, varied with both the age of the culture $\left(p<2.2 .10^{-16}\right.$ for both parameters) and the gellan gum concentration $(p<$ $5.71 .10^{-16}$ and $p<5.16 .10^{-13}$ respectively), and their maximum DW content coincided with their lowest water content. The between-treatment differences in results could be due to the significant decrease in water availability on the $8 \mathrm{gL}^{-1}$ compared to the $4 \mathrm{gL}^{-1}$ gellan gum $(593.9 \pm 4.0 \mathrm{mg}$ vs. $620.5 \pm 15.2$ $\mathrm{mg}$, respectively; $\mathrm{n}=5, p=0.002$ ).

The osmotic potential ( $\Psi$ ) of the embryos grown in both media, and the media, was measured at various maturation stages. The media with no culture showed no variation of $\Psi$, regardless of the gellan gum level or maturation time (data not shown). In contrast, in the presence of embryos, at the 8week stage the $\Psi$ of the $8 \mathrm{gL}^{-1}$ gellan gum medium was significantly lower $(p=0.00107)$ than that of the $4 \mathrm{gL}^{-1}$ medium (Fig. 2). The $\Psi$ of embryos was lower at all maturation stages than that of all media. During embryo maturation, no effect of gellan gum concentration on their $\Psi$ was detected $(p=$ $0.28114)$. However at the 8 -week stage, $\Psi$ was lower in embryos exposed to the gellan gum at $8 \mathrm{gL}^{-1}$ than at counterparts exposed to $4 \mathrm{gL}^{-1}(p=0.0023)$.

\section{Protein patterns}

Soluble protein profiles of embryos exposed to $4 \mathrm{gL}^{-1}$ or $8 \mathrm{gL}^{-1}$ gellan gum in the medium, and sampled at 1 and 8 weeks of maturation were determined using 2D-gel electrophoresis. Variation in the relative abundance of 1188 consistent spots was evaluated. Their distribution in samples from embryos exposed to 4 and $8 \mathrm{gL}^{-1}$ gellan gum at 1 and 8 weeks of maturation are shown in Fig 3. Sixtyfour percent $(759 / 1188)$ of the proteins were common to all stages, $16 \%$ were common to a given maturation time regardless of the gellan gum content, $7.6 \%$ were specific to $4 \mathrm{gL}^{-1}$ gellan gum samples, and $6.4 \%$ were specific to $8 \mathrm{gL}^{-1}$ gellan gum samples (Fig. 3). The total number of detected spots was similar in samples exposed to both gellan gum concentrations. The analysis of the spot pattern revealed that most of the spots did not significantly differ in volume according to the gellan gum concentrations. Sixty two spots displayed significant differences in their normalized volume at 1 week of maturation, and 49 spots at 8 weeks of maturation. Among these significant spots at stages 1 and 8 weeks of maturation, only three were in common (spots \#88, 367 and 962). They were identified as Ras-related protein Rab2B (\#88), glucose-regulated protein homolog 4 (\#367) and an undocumented protein annotated as chromosome chr5 scaffold-67 (\#962).

Among 62 significant spots at 1 week of maturation, 56 were reliably identified using at least two peptides (Table 1 and Fig. 4). Six spots displayed more than one putative protein identity and were discarded for further analysis (see Appendix S1 in Supporting Information). 
Two thirds of all identified proteins displayed a significant increase in abundance when the embryos were cultivated with $4 \mathrm{gL}^{-1}$ gellan gum, and one third when the embryos were cultivated with $8 \mathrm{gL}^{-1}$ gellan gum. The identified proteins were classified according to their functional categories (Table 2). Most of the proteins fell into the "Metabolism" category (38\%). Forty one percent of these proteins are involved in carbohydrate metabolism, mainly in gluconeogenesis. Proteins involved in environmental information processing were over-expressed only on the $8 \mathrm{gL}^{-1}$ gellan gum medium.

\section{Discussion:}

\section{Effects of increasing the gellan gum concentration on physiological parameters}

Increasing the gellan gum concentration in the maturation media has been found to greatly improve the recovery of SEs of various pine species (Klimaszewska et al., 2007), including Pinus strobus (Klimaszewska and Smith 1997), Pinus pinaster and Pinus sylvestris (Lelu et al. 1999) and, recently, hybrid larch (Lelu-Walter and Pâques 2009). Increasing the gellan gum concentration from 4 to $8 \mathrm{gL}^{-1}$ greatly enhanced the recovery of cotyledonary SEs, which could subsequently germinate and develop into plantlets at a high rate. The results of the present study show that the high gellan gum level $\left(8 \mathrm{gL}^{-}\right.$ ${ }^{1}$ ) resulted in a DW increase in the somatic embryos, accompanied by a reduction in their water content throughout maturation. At the end of the experiment their water content was $2.44 \mathrm{~g} \mathrm{H}_{2} \mathrm{O} / \mathrm{g}$ DW, very similar to values previously recorded when somatic embryos were subjected to a desiccation treatment (Lelu et al. 1995). Therefore, our results suggest that use of $8 \mathrm{gL}^{-1}$ gellan gum, rather than 4 $\mathrm{gL}^{-1}$, beneficially enhances dehydration of the SEs.

Accordingly, water availability was found to be lower in filter papers placed on the $8 \mathrm{gL}^{-1}$ medium than in others placed on the $4 \mathrm{gL}^{-1}$ medium, indicating that water could be less readily taken up by the cultures from the medium, and this could be linked to the lower quantity of water found in the SEs cultivated on the $8 \mathrm{gL}^{-1}$ medium. Nevertheless, those SEs accumulated more DW than counterparts cultivated on the $4 \mathrm{gL}^{-1}$ medium. Therefore, the results indicate that the development of SEs was enhanced rather than limited by the reduced water availability on the medium with the higher gel content.

It should be noted that the amount of water in the two media was almost identical, since only the gellan gum concentration varied, implying that the gel strength differed substantially between them but their water potential was very similar, as observed in the absence of embryo cultures (results not shown). In contrast, when growing SEs were present, the $8 \mathrm{gL}^{-1}$ culture medium had a lower $\Psi$ than the $4 \mathrm{gL}^{-1}$ medium. Similarly, cotyledonary somatic embryos that developed on the $8 \mathrm{gL}^{-1}$ medium had lower $\Psi$ than counterparts on the $4 \mathrm{gL}^{-1}$ medium. Hence, the results suggest that since water is less available in the medium with $8 \mathrm{gL}^{-1}$ gum, SEs might possess mechanisms that adjust their $\Psi$ sufficiently to ensure that transfer of the water from the medium occurs (within physiological 
limitations). These results are in agreement with observations of similar phenomena in Pinus strobus by Klimaszewska et al. (2000). This hypothetical adjustment of the SE $\Psi$ to water availability could explain the greater dehydration observed in the SEs cultivated on $8 \mathrm{gL}^{-1}$.

\section{Effect of increasing gellan gum concentration on protein relative abundance}

We evaluated and compared the soluble protein patterns in SEs cultivated on the two media during their maturation by 2-D gel analysis, and detected 62 spots corresponding to proteins that appeared to be differentially expressed. The corresponding proteins were successfully identified in 56 of these spots by MS/MS; a similar success rate $(90.3 \%)$ to rates obtained in proteomic analyses of other types of plant tissues, e.g. 75, 91.2, 78 and 77\%, respectively, in analyses of Pinus pinaster wood-forming tissue (Gion et al. 2005), eight Populus trichocharpa tissues (Plomion et al. 2006), Pinus abies seedlings (Valcu et al. 2008) and Pinus radiata needles (Valledor et al. 2008). However, levels of coverage and the numbers of identifiable peptide fragments generated per spot were low compared to those generally obtained (Yang et al. 2007, Bonhomme et al. 2009). This can be explained by the limited genomic resources available for conifers, especially Larix. It should also be noted that for six spots more than one protein was identified, a phenomenon that has been previously reported by several authors (Gion et al. 2005, Jorge et al. 2005, Jorge et al. 2006, Valledor et al. 2008, Pan et al. 2009). In some cases this may be due to degradation products of some proteins such as RubisCo (spot \#271), which are often detected in proteomic studies (Gion et al. 2005, Jorge et al. 2006, Valledor et al. 2008) and may comigrate with other proteins. In other cases it may be due to the presence of multiple isoforms of a protein, e.g. in the present study two isoforms of enolase, a marker of embryogenic maturation (Lippert et al. 2005), were found to be differentially expressed in SEs cultivated on the 4 $\mathrm{gL}^{-1}$ and $8 \mathrm{gL}^{-1}$ gum media (spots \#294 and 763). The presence of protein isoforms with different expression patterns during seed maturation has already been reported in barley (Finnie et al. 2006).

In studies of the effects of water deficits in intact plants, decreased levels of proteins involved in carbon metabolism and protein have often been found (Jorge et al. 2006, Plomion et al. 2006, Bonhomme et al. 2009). Accordingly, seven of the proteins identified as being differentially expressed in the present study are involved in the glycolysis/gluconeogenesis pathway (alcohol dehydrogenase, dihydrolipoyl dehydrogenase, enolase, fructose-bisphosphate aldolase, glucose-6-phosphate isomerase, phosphoglucomutase and pyruvate decarboxylase), and all were expressed more weakly in SEs cultivated on the medium with $8 \mathrm{gL}^{-1}$ gellan gum. Pyruvate decarboxylase, the only one of these enzymes to catalyse an essentially irreversible reaction, plays an important role in determining how much of the cell's carbon is directed towards catabolism via glycolysis. The presumably accompanying reduction in rates of carbon catabolism may promote the observed increase in dry weight of the embryos cultivated on the $8 \mathrm{gL}^{-1}$ medium. The glucose in these embryos participates in the observed increase of osmotic potential. The enzyme fructose-biphosphate aldolase, which was down-regulated in the SEs cultivated on the $8 \mathrm{gL}^{-1}$ medium, is involved in many pathways, including 
glycolysis/gluconeogenesis, the pentose phosphate pathway, fructose and mannose metabolism, and the Calvin cycle. The three first belong to carbohydrate anabolism, the last one belongs to the carbohydrate catabolism. A decrease of activity in the Calvin cycle leads to a decrease in carbohydrate synthesis, while a decrease in fluxes through the pentose phosphate cycle implies a decrease in glycolysis and hence enhanced production of nucleic acid precursors. The decreased abundance of enzymes involved in glycolysis could be related to the increased dry weight of SEs cultured on the medium with $8 \mathrm{gL}^{-1}$ gum observed in this study.

Modification of the somatic embryogenesis culture medium also induced changes in the abundance of proteins involved in the protection of the cell, including detoxification processes and protection of cellular components. The proteins flavanone 3-hydroxylase and aspartate aminotransferase, which were more abundant in SEs cultivated on medium with $4 \mathrm{gL}^{-1}$ gel, are involved in secondary metabolism. Secondary metabolism is reportedly more active in plants under stresses that lead to increased production of free radicals (Edreva et al., 2008), which could explain why one of the proteins found to be expressed more strongly in SEs cultivated with $4 \mathrm{gL}^{-1}$ of gellan gum included superoxide dismutase. Furthermore, several Heat Shock Proteins (HSPs) were found to be differentially expressed (HSP70, HSP81, HSP90, HSP101 and GRP94), all but one of which were more abundant in the SEs cultivated on the $4 \mathrm{gL}^{-1}$ medium. These proteins could be involved in the assembly and stabilization of newly synthesized proteins during cell division and expansion (Sung et al. 2001, Wang et al. 2004). HSPs are generally more abundant in zygotic than in somatic embryos (Sghaier-Hammami et al. 2009), and they are especially abundant in late stages of embryo maturation, their accumulation being induced by seed dehydration. At 1 week, SEs still contain about $90 \%$ water. Since this does not suggest water stress, the presence of HSPs could indicate the presence of other types of abiotic stresses (Lee and Schoffl 1996, Marsoni et al. 2008). Intriguingly, the need for both cell detoxification and stabilization of proteins by HSPs appears to be greater when the maturation of embryos occurs in the presence of $4 \mathrm{gL}^{-1}$ gellan gum than when $8 \mathrm{gL}^{-1}$ is present.

Despite these indications that the SEs cultivated on the medium with $4 \mathrm{gL}^{-1}$ gum may have been stressed, water availability and $\Psi$ were lower in the medium with $8 \mathrm{gL}^{-1}$ gum, indicating that the latter may have induced drought stress. However, this hypothesis was not supported by the profiles of various proteins that are reportedly induced by drought, either directly or indirectly, including 6phosphogluconate dehydrogenase (decarboxylating), actin, enolase, fructose phosphate aldolase, phosphoglucomutase and superoxide dismutase (Costa et al. 1998, Riccardi et al. 1998, Salekdeh et al. 2002, Tausz et al. 2004, Ali and Komatsu 2006, Jorge et al. 2006, Plomion et al. 2006). On the basis of observed profiles of these proteins, we therefore cannot infer the presence of such a stress under these conditions. Indeed, they were among the 56 identified differentially expressed proteins that were expressed more strongly in SEs cultivated on the $4 \mathrm{gL}^{-1}$ medium. Two of them, 6-phosphogluconate dehydrogenase and fructose phosphate aldolase, are key metabolic enzymes, the first being involved in the pentose phosphate pathway, while superoxide dismutase catalyses conversion of the superoxide 
radical to $\mathrm{H}_{2} \mathrm{O}_{2}$ and plays a key role in detoxification processes (Alscher et al. 2002). Overexpression of the corresponding gene has also been shown to enhance tolerance to salt, water, and osmotic stresses in tobacco (Badawi et al. 2004). In addition to the increased abundance of HSPs in SEs cultivated on the $4 \mathrm{gL}^{-1}$ medium, the observed increases in expression of pyruvate decarboxylase (which directs carbon metabolism towards glycolysis) and apparent detoxification capacity (indicated by the increased expression of superoxide dismutase) suggest that maturation on medium containing 4 $\mathrm{gL}^{-1}$ gum may induce stress in the embryo culture.

In contrast, observed increases in the abundance of actin and type Ras protein in SEs cultivated with 8 $\mathrm{gL}^{-1}$ gum indicated that cell division is more active on this medium, and this was confirmed for later stages, since the total protein content and dry content measurements showed that these SEs had matured more fully. Furthermore, many studies have shown that the length of the maturation period of somatic embryos plays an important role in promoting desiccation tolerance (Attree et al. 1992), but also that partial or full desiccation of coniferous somatic embryos has a positive effect on subsequent plantlet development (Attree et al. 1991, Lelu et al. 1995). The qualitative improvement described by Lelu and Paques (2009) could be attributed to the decrease of water content in embryos during maturation.

In conclusion, the data presented here describe the physiological effects of an increase of gellan gum in the medium used to culture SEs of hybrid larch; we observed a decrease in osmotic potential and water content, and an increase in DW. The putatively identified differentially abundant proteins suggest that the embryos' physiological status was better on the medium with the higher gellan gum concentration, as indicated by the reductions in abundance of enzymes involved in the glycolysis pathway and HSPs. This is the first report of a 2-DE proteomic analysis of conifer somatic embryo maturation in the presence of gelling agent at high concentration, and the first published proteomic analysis of Larix. There is a general lack of molecular information related to conifer SE maturation at the protein level, and further studies are required to clarify the involvement of individual proteins in the maturation process.

\section{Acknowledgements}

This research was supported by a grant from Région Aquitaine (Région Aquitaine biotechno pin) and by INRA EFPA. The authors are grateful to Aurélien Barré from the "Centre de Bioinformatique de Bordeaux" for expert help with BLAST analyses. The authors gratefully thank Patrick von Aderkas for critical discussion and improvement of the manuscript.

\section{References}

Ali GM, Komatsu S (2006) Proteomic analysis of rice leaf sheath during drought stress. J. Prot. Res. 5: $396-403$ 
Alscher RG, Erturk N, Heath LS (2002) Role of superoxide dismutases (SODs) in controlling oxidative stress in plants. J. Exp. Bot. 53: 1331-1341

Attree SM, Moore D, Sawhney VK, Fowke LC (1991) Enhanced maturation and desiccation tolerance of white spruce [Picea glauca (Moench) Voss] somatic embryos: Effects of a non-plasmolysing water stress and abscisic acid. Ann. Bot. 68: 519-525

Attree SM, Pomeroy MK, Fowke LC (1992) Manipulation of conditions for the culture of somatic embryos of white spruce for improved triacylglycerol biosynthesis and desiccation tolerance. Planta 187: $395-404$

Attree SM, Pomeroy MK, Fowke LC (1995) Development of white spruce (Picea glauca (Moench.) Voss) somatic embryos during culture with abscisic acid and osmoticum, and their tolerance to drying and frozen storage. J. Exp. Bot. 46: 433-439

Badawi GH, Yamauchi Y, Shimada E, Sasaki R, Kawano N, Tanaka K, Tanaka K (2004) Enhanced tolerance to salt stress and water deficit by overexpressing superoxide dismutase in tobacco (Nicotiana tabacum) chloroplasts. Plant Sci. 166: 919-928

Becwar MR, Nagmani R, Wann SR (1990) Initiation of embryogenic cultures and somatic embryo development in loblolly pine (Pinus taeda). Can. J. Bot. 20: 810-817

Bonhomme L, Monclus R, Vincent D, Carpin S, Claverol S, Lomenech A-M, Labas V, Plomion C, Brignolas F, Morabito D (2009) Genetic variation and drought response in two Populus $x$ euramericana genotypes through 2-DE proteomic analysis of leaves from field and glasshouse cultivated plants. Phytochemistry 70: 988-1002

Bonhomme L, Monclus R, Vincent D, Carpin S, Lomenech A-M, Plomion C, Brignolas F, Morabito D (2009) Leaf proteome analysis of eight Populus xeuramericana genotypes: Genetic variation in drought response and in water-use efficiency involves photosynthesis-related proteins. PROTEOMICS 9: 4121-4142

Bradford KJ (1994) Water stress and the water relations of seed development: A critical review. Crop Sci. 34: 1-11

Costa P, Bahrman N, Frigerio J-M, Antoine K, Christophe P (1998) Water-deficit-responsive proteins in maritime pine. Plant Mol. Biol. 38: 587-596

Damerval C, De Vienne D, Zivy M, Thiellement H (1986) Technical improvements in twodimensional electrophoresis increase the level of genetic variation detected in wheat-seedling proteins. Electrophoresis 7: 52-54

Dronne S, Label P, Lelu M-A (1997) Desiccation decreases abscisic acid content in hybrid larch (Larix $\times$ leptoeuropaea) somatic embryos. Physiologia Plantarum 99: 433-438 
Finnie C, Bak-Jensen KS, Laugesen S, Roepstorff P, Svensson B (2006) Differential appearance of isoforms and cultivar variation in protein temporal profiles revealed in the maturing barley grain proteome. Plant Sci. 170: 808-821

Gion J-M, Lalanne C, Le Provost G, Ferry-Dumazet H, Paiva J, Chaumeil P, Frigerio J-M, Brach J, Barré A, de Daruvar A, Claverol S, Bonneu M, Sommerer N, Negroni L, Plomion C (2005) The proteome of maritime pine wood forming tissue. PROTEOMICS 5: 3731-3751

Guillaumot D, Lelu-Walter M-A, Germot A, Meytraud F, Gastinel L, Riou-Khamlichi C (2008) Expression patterns of LmAP2L1 and LmAP2L2 encoding two-APETALA2 domain proteins during somatic embryogenesis and germination of hybrid larch (Larix $\times$ marschlinsii). J. Plant Physiol. 165: 1003-1010

Gutmann M, von Aderkas P, Label P, Lelu M-A (1996) Effects of abscisic acid on somatic embryo maturation of hybrid larch. J. Exp. Bot. 47: 1905-1917

Hakman I, Stabel P, Engström P, Eriksson T (1990) Storage protein accumulation during zygotic and somatic embryo development in Picea abies (Norway spruce). Physiol. Plant. 80: 441-445

Hou F-Y, Huang J, Yu S-L, Zhang H-S (2007) The 6-phosphogluconate dehydrogenase genes are responsive to abiotic stresses in rice. J. Integr. Plant Biol. 49: 655-663

Jorge I, M. Navarro R, Lenz C, Ariza D, Porras C, Jorrín J (2005) The Holm Oak leaf proteome: Analytical and biological variability in the protein expression level assessed by 2-DE and protein identification tandem mass spectrometry de novo sequencing and sequence similarity searching. PROTEOMICS 5: 222-234

Jorge I, Navarro RM, Lenz C, Ariza D, Jorrín J (2006) Variation in the holm oak leaf proteome at different plant developmental stages, between provenances and in response to drought stress. PROTEOMICS 6: S207-S214

Kermode AR (1990) Regulatory mechanisms involved in the transition from seed development to germination. Crit. Rev. Plant Sci. 9: 155-195

Klimaszewska K, Smith DR (1997) Maturation of somatic embryos of Pinus strobus is promoted by a high concentration of gellan gum. Physiol. Plant. 100: 949-957

Klimaszewska K, Bernier-Cardou M, Cyr DR, Sutton BCS (2000) Influence of gelling agents on culture medium gel strength, water availability, tissue water potential, and maturation response in embryogenic cultures of Pinus strobus L. In Vitro Cell. Dev. Biol. Plant 36: 279-286

Klimaszewska K, Morency F, Jones-Overton C, Cooke J (2004) Accumulation pattern and identification of seed storage proteins in zygotic embryos of Pinus strobus and in somatic embryos from different maturation treatments. Physiol. Plant. 121: 682-690

Klimaszewska K, Trontin J-F, Becwar M, Devillard C, Park Y-S, Lelu-Walter M-A (2007) Recent progress in somatic embryogenesis of four Pinus spp. Tree For. Sci. Biotech. 1: 11-25 maturation in hybrid larch (Larix $\times$ eurolepsis): a 2-DE proteomic analysis. Physiologia 
Lee JH, Schoffl F (1996) An Hsp70 antisense gene affects the expression of HSP70/HSC70, the regulation of HSF, and the acquisition of thermotolerance in transgenic Arabidopsis Thaliana, Vol 252. Springer, Berlin, Germany

Lelu M-A, Label P (1994) Changes in the levels of abscisic acid and its glucose ester conjugate during maturation of hybrid larch (Larix $\times$ leptoeuropaea) somatic embryos, in relation to germination and plantlet recovery. Physiol. Plant. 92: 53-60

Lelu M-A, Klimaszewska K, Pflaum G, Bastien C (1995) Effect of maturation duration on desiccation tolerance in hybrid larch (Larix x Leptoeuropaea dengler) somatic embryos. In vitro Cell Dev. Biol. 31: $15-20$

Lelu M-A, Bastien C, Drugeault A, Gouez M-L, Klimaszewska K (1999) Somatic embryogenesis and plantlet development in Pinus sylvestris and Pinus pinaster on medium with and without growth regulators. Physiol. Plant. 105: 719-728

Lelu-Walter M-A, Bernier-Cardou M, Klimaszewska K (2006) Simplified and improved somatic embryogenesis for clonal propagation of Pinus pinaster (Ait.). Plant Cell Rep. 25: 767-776

Lelu-Walter M-A, Bernier-Cardou M, Klimaszewska K (2008) Clonal plant production from self- and cross-pollinated seed families of Pinus sylvestris (L.) through somatic embryogenesis. Plant Cell Tissue Organ Cult. 92: 31-45

Lelu-Walter M-A, Pâques LE (2009) Simplified and improved somatic embryogenesis of hybrid larches (Larix x eurolepis and Larix x marschlinsii). Perspectives for breeding. Ann. For. Sci. 66: 104

Lippert D, Jun Z, Ralph S, Ellis DE, Gilbert M, Olafson R, Ritland K, Ellis B, Douglas CJ, Bohlmann J (2005) Proteome analysis of early somatic embryogenesis in Picea glauca. PROTEOMICS 5: 461473

Marsoni M, Bracale M, Espen L, Prinsi B, Negri AS, Vannini C (2008) Proteomic analysis of somatic embryogenesis in Vitis vinifera. Plant Cell Rep. 27: 209-409

Mathieu M, Lelu-Walter M-A, Blervacq AS, David H, Hawkins S, Neutelings G (2006) Germin-like genes are expressed during somatic embryogenesis and early development of conifers. Plant Mol. Biol. 61: 615-627

Pan Z, Guan R, Zhu S, Deng X (2009) Proteomic analysis of somatic embryogenesis in Valencia sweet orange (Citrus sinensis Osbeck). Plant Cell Rep. 28: 281-289

Pâques LE (1992) Performance of vegetatively propagated Larix decidua, L. kaempferi and L. laricina hybrids. Ann. Sci. For. 49: 63-74

Plomion C, Lalanne C, Claverol S, Meddour H, Kohler A, Bogeat-Triboulot M-B, Barre A, Le Provost G, Dumazet H, Jacob D, Bastien C, Dreyer E, de Daruvar A, Guehl J-M, Schmitter J-M, Martin F, Bonneu M (2006) Mapping the proteome of poplar and application to the discovery of drought-stress responsive proteins. PROTEOMICS 6: 6509-6527 
Ramagli LS, Rodriguez LV (1985) Quantitation of microgram amounts of protein in two-dimensional polyacrylamide electrophoresis sample buffer. Electrophoresis 6: 559-563

Riccardi F, Gazeau P, de Vienne D, Zivy M (1998) Protein changes in response to progressive water deficit in maize. Quantitative variation and polypeptide identification. Plant Physiology 117: 12531263

Roberts DR, Flinn BS, Webb DT, Webster FB, Sutton BCS (1990) Abscisic acid and indole-3-butyric acid regulation of maturation and accumulation of storage proteins in somatic embryos of interior spruce. Physiol. Plant. 78: 355-360

Salekdeh GH, Siopongco J, Wade LJ, Ghareyazie B, Bennett J (2002) Proteomic analysis of rice leaves during drought stress and recovery. PROTEOMICS 2: 1131-1145

Sallandrouze A, Faurobert M, El Maataoui M, Espagnac H (1999) Two-dimensional electrophoretic analysis of proteins associated with somatic embryogenesis development in Cupressus sempervirens L. Electrophoresis 20: 1109-1119

Sghaier-Hammami B, Drira N, Jorrín-Novo JV (2009) Comparative 2-DE proteomic analysis of date palm (Phoenix dactylifera L.) somatic and zygotic embryos. J. Proteomics 73: 161-177

Sung D-Y, Kaplan F, Guy CL (2001) Plant Hsp70 molecular chaperones: Protein structure, gene family, expression and function. Physiol. Plant. 113: 443-451

Tausz M, Pilch B, Herschbach C, Rennenberg H, Grill D (2004) Uptake, transport and metabolisation of glutathione in seedlings of Phaseolus vulgaris L. J. Plant Physiol. 161: 347-349

Valcu C-M, Lalanne C, Plomion C, Schlink K (2008) Heat induced changes in protein expression profiles of Norway spruce (Picea abies) ecotypes from different elevations. PROTEOMICS 8: 42874302

Valledor L, Castillejo MA, Lenz C, Rodriguez R, Canal MJ, Jorrin J (2008) Proteomic analysis of Pinus radiata needles: 2-DE map and protein identification by LC/MS/MS and substitution-tolerant database searching. J. Prot. Res. 7: 2616-2631

von Aderkas P, Lelu M-A, Label P (2001) Plant growth regulator levels during maturation of larch somatic embryos. Plant physiol. Biochem. 39: 495-502

Wang W, Vinocur B, Shoseyov O, Altman A (2004) Role of plant heat-shock proteins and molecular chaperones in the abiotic stress response. Trends Plant Sci. 9: 244-252

Yang P, Li X, Wang X, Chen H, Chen F, Shen S (2007) Proteomic analysis of rice (Oryza sativa) seeds during germination. PROTEOMICS 7: 3358-3368 


\section{Figure legends}

Figure 1: Percentage of dry weight (A) and water content (B) in embryos during maturation according to gellan gum concentration. Error bars represent standard error $(n=9)$. Significantly different groups are indicated by different letters $(p=0.05)$.

Figure 2: Change with time in osmotic potential $\left(\Psi_{\pi}\right)$ of the culture media and somatic embryos during maturation according to gellan gum concentration. Error bars represent standard error ( $\mathrm{n}=8$ for media and $n=10$ for tissues). Significantly different groups are indicated by different letters (multiple comparison of means: $p=0.05$ ).

Figure 3 : Venn diagram showing distributions of the total number of spots (1188) between the different stages. Values in rectangular boxes indicate the total number of spots per stage.

Figure 4 : Representative 2-DE map obtained for SEs after eight weeks of maturation on $8 \mathrm{gL}^{-1}$ gellan gum. Marked spots displayed significant differences in their abundance $(p<0.05)$ between SEs cultivated on medium with 4 and $8 \mathrm{gL}^{-1}$ gellan gum. 

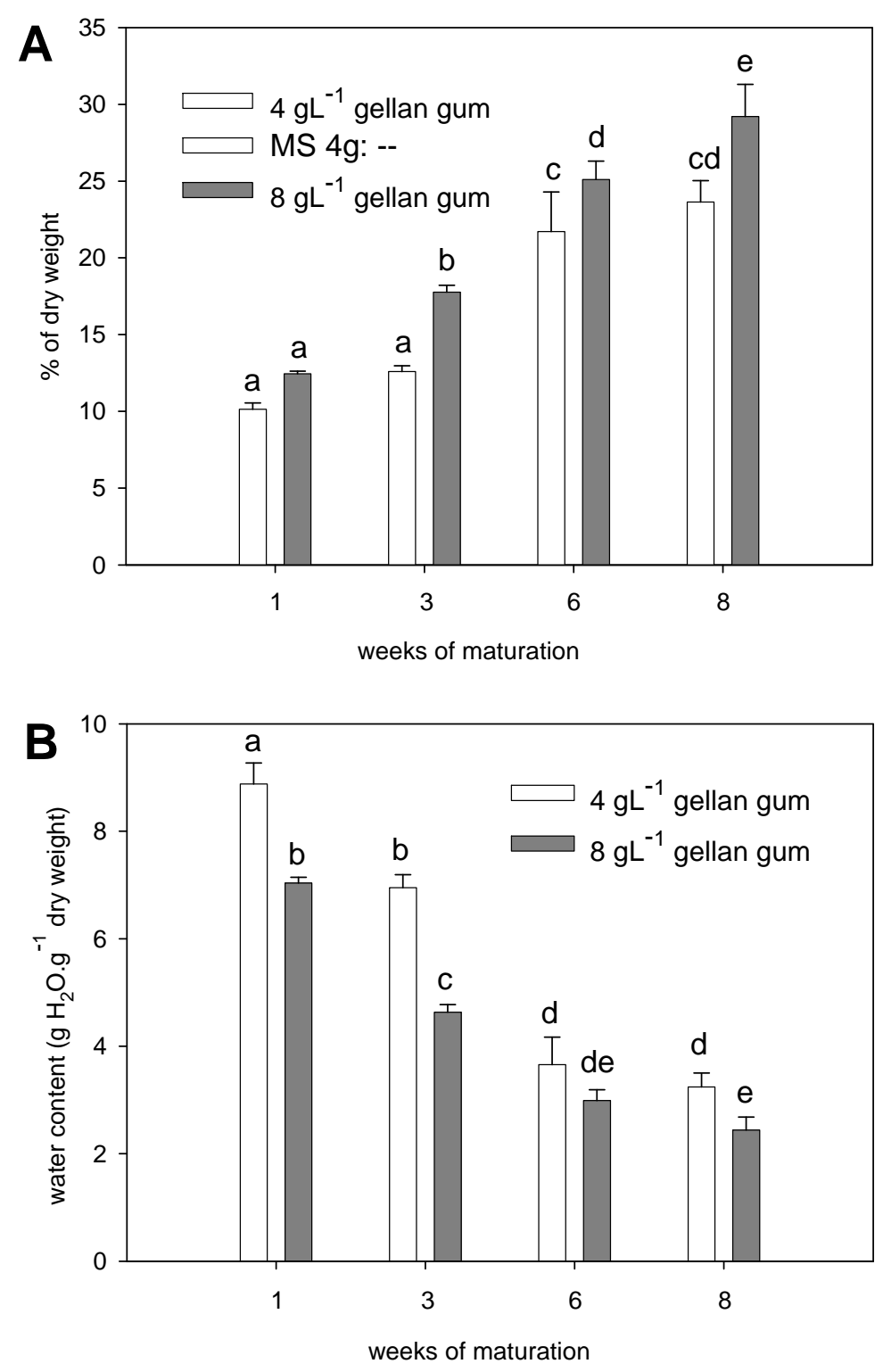

Figure 1 


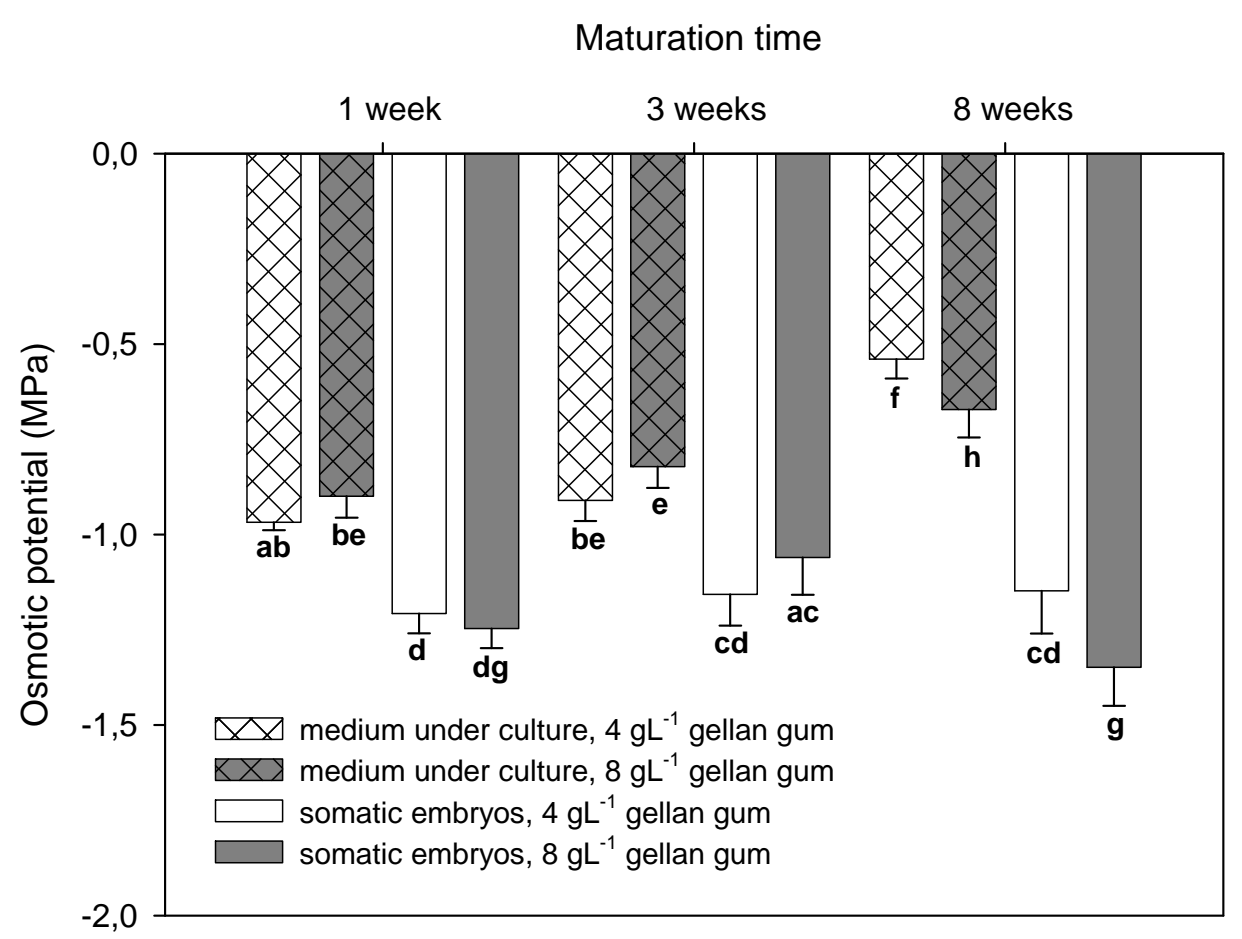

Figure 2 


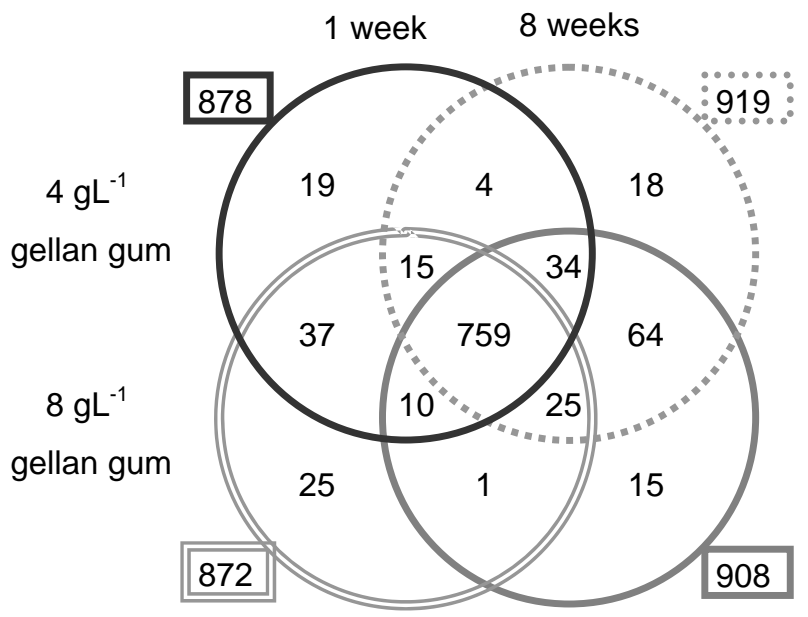

Figure 3 


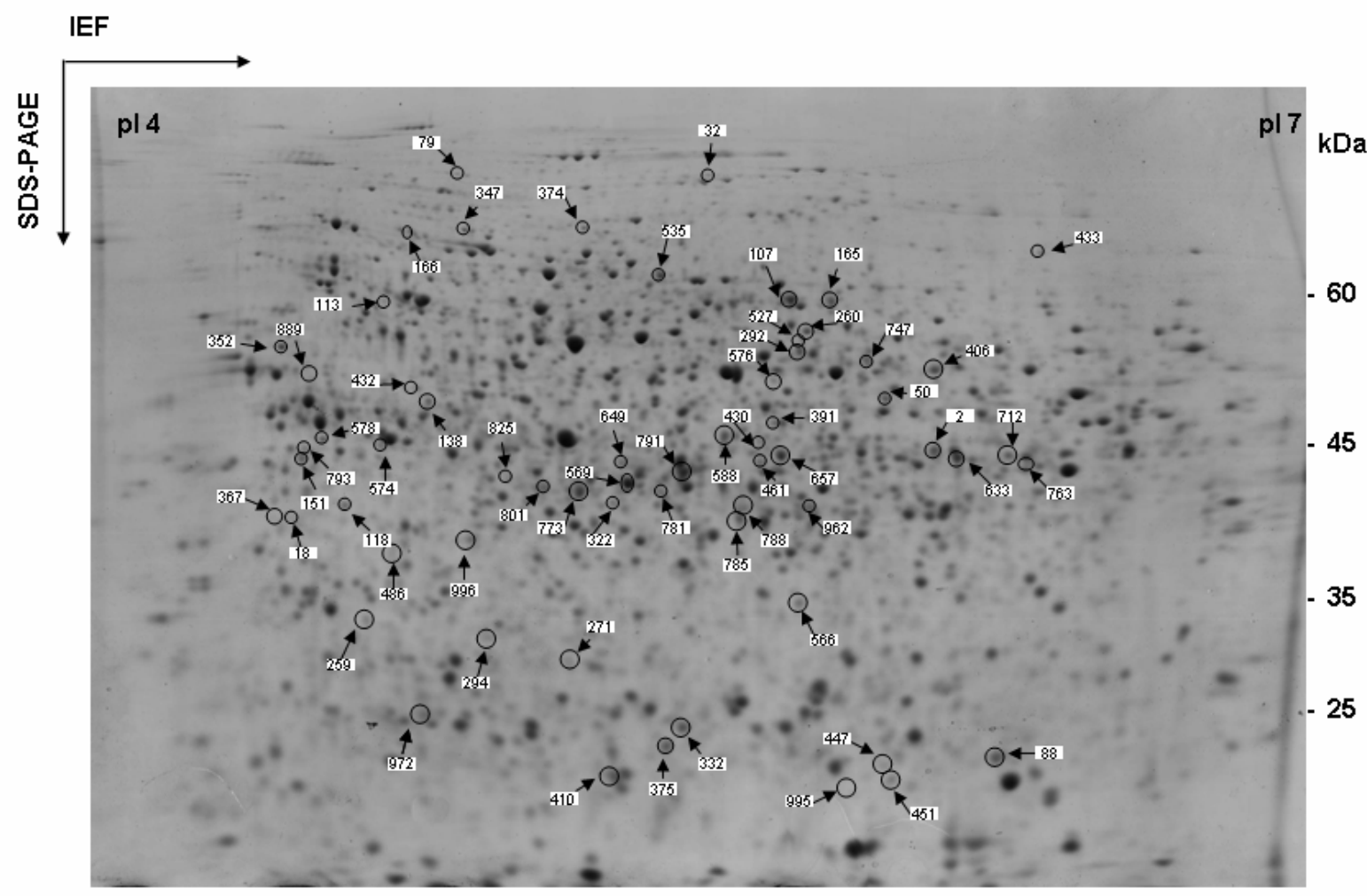

\section{Figure 4}


Tables

Table 1: Identification of proteins according to gellan gum level in the culture medium.

Putative proteins more abundant in SE cultured on $4 \mathrm{gL}^{-1}$ gellan gum compared to $8 \mathrm{gL}^{-1}$

\begin{tabular}{|c|c|c|c|c|c|c|c|c|c|c|}
\hline \multirow[t]{2}{*}{$\begin{array}{l}\text { Spot } \\
\text { no. }^{a}\end{array}$} & \multirow[t]{2}{*}{ Assignment } & \multirow[t]{2}{*}{$\mathbf{T C}^{\mathbf{b}}$} & \multirow[t]{2}{*}{$\begin{array}{c}\# \\
\text { pep. }^{c}\end{array}$} & \multirow[t]{2}{*}{$\begin{array}{c}\% \\
\text { cov. }\end{array}$} & \multirow{2}{*}{$\begin{array}{c}\text { Accession } \\
\text { no. }{ }^{\text {e }}\end{array}$} & \multirow[t]{2}{*}{ Species } & \multicolumn{2}{|c|}{ Theoretical } & \multicolumn{2}{|c|}{ Experimental } \\
\hline & & & & & & & $\mathrm{Mr}(\mathbf{D a})$ & pI & $\mathbf{M r}(\mathbf{D a})$ & $\overline{p I}$ \\
\hline \multirow[t]{2}{*}{18} & Heat shock cognate $70 \mathrm{kDa}$ protein & TC105009 & 2 & 6.4 & Q9M6R1 & Malus x domestica & 71216 & 5.2 & 39101 & 4.9 \\
\hline & GRP94 & TC110737 & 3 & 9.3 & A7YAU9 & Pinus taeda & 95380 & 4.8 & & \\
\hline \multirow[t]{2}{*}{50} & Argininosuccinate synthase & gi|90042890 & 3 & 3.0 & & Medicago truncatula & 63733 & & 51840 & 5.9 \\
\hline & Argininosuccinate synthase & ТC95974 & 1 & 5.2 & A9TX31 & Physcomitrella patens & 52392 & 6.0 & & \\
\hline \multirow[t]{2}{*}{107} & Pyruvate decarboxylase isozyme 2 & TC81547 & 4 & 4.8 & Q9FVF0 & Fragaria $x$ ananassa & 64847 & 5.9 & 60204 & 5.8 \\
\hline & Pyruvate decarboxylase isozyme 2 & TC88813 & 2 & 9.4 & Q84V95 & Lotus corniculatus & 65132 & 5.9 & & \\
\hline \multirow[t]{2}{*}{113} & Glucose-6-phosphate isomerase cytosolic & TC107785 & 2 & & Q9FXM5 & Spinacia oleracea & 61754 & 6.4 & 59629 & 5.1 \\
\hline & Glucose-6-phosphate isomerase cytosolic A & TC81691 & 4 & 6.9 & Q8H8M6 & Vitis vinifera & 62524 & 6.8 & & \\
\hline 118 & Endoplasmin homolog & TC110737 & 3 & 9.3 & P35016 & Catharanthus roseus & 93492 & 4.9 & 41975 & 5.0 \\
\hline \multirow[t]{2}{*}{138} & RPT2A; ATPase & gi|90038952 & 4 & 10.0 & & Arabidopsis thaliana & 54652 & & 51169 & 5.2 \\
\hline & AAA ATPase; 26S proteasome subunit P45 & TC 80721 & 1 & 3.6 & Q2HTA3 & Medicago truncatula & 49488 & 5.9 & & \\
\hline \multirow[t]{4}{*}{151} & Heat shock protein $81-1$ & TC101959 & 3 & 12.7 & A2YWQ1 & Oryza sativa & 80194 & 5.0 & 44273 & 5.0 \\
\hline & Heat shock protein $81-3$ & TC108803 & 5 & 8.0 & P51818 & Arabidopsis thaliana & 80052 & 5.0 & & \\
\hline & Molecular chaperone Hsp90-1 & TC96311 & 2 & 12.2 & Q6UJX6 & Nicotiana benthamiana & 80105 & 4.9 & & \\
\hline & Hsp90-2-like & TC98348 & 2 & 12.3 & Q2XTE5 & Solanum tuberosum & 80417 & 5.1 & & \\
\hline \multirow[t]{2}{*}{165} & Pyruvate decarboxylase & TC81547 & 5 & 3.5 & Q9FVF0 & Fragaria ananassa & 65244 & 5.9 & 60044 & 5.9 \\
\hline & Pyruvate decarboxylase & TC81434 & 3 & 4.3 & Q84V95 & Lotus corniculatus & 65132 & 5.9 & & \\
\hline 294 & Enolase 1 & TC 80765 & 5 & 5.4 & Q9LEJ0 & Hevea brasiliensis & 47830 & 5.6 & 31088 & 5.3 \\
\hline 347 & Oligopeptidase A & TC100165 & 2 & 3.7 & A9YWR9 & Medicago truncatula & 79121 & 5.4 & 67068 & 5.2 \\
\hline 352 & GRP94 & TC101142 & 3 & 9.0 & A7YAU9 & Pinus taeda & 95380 & 4.8 & 54426 & 4.9 \\
\hline 391 & Chalconeflavonone $\mathrm{i}$ & TC99105 & 2 & 9.1 & A5HBK6 & Pyrus communi & 23364 & 5.6 & 49669 & 5.8 \\
\hline 430 & Dihydrolipoyl dehydrogenase 1 mitochondrial & TC99823 & 2 & 3.8 & Q9LNF3 & Arabidopsis thaliana & 53988 & 7.0 & 48487 & 5.7 \\
\hline 461 & 3-isopropylmalate dehydrogenase & TC83730 & 7 & 19.7 & A2XK82 & Oryza sativa & 41747 & 5.3 & 46412 & 5.7 \\
\hline \multirow[t]{3}{*}{486} & Heat shock protein 812 & TC113528 & 2 & 5.1 & P55737 & Arabidopsis thaliana & 80064 & 5.0 & 37186 & 5.1 \\
\hline & Heat shock $70 \mathrm{kDa}$ protein mitochondrial & TC114628 & 2 & 5.2 & Q01899 & Phaseolus vulgaris & 72537 & 6.0 & & \\
\hline & Heat shock $70 \mathrm{kDa}$ protein mitochondrial & TC98916 & 3 & 8.7 & Q08276 & Solanum tuberosum & 73077 & 6.4 & & \\
\hline
\end{tabular}


535 Phosphoglucomutase

Phosphoglucomutase

574 Chromosome chr8 scaffold_29

578 Heat shock protein $81-3$

588 Alcohol dehydrogenase

Alcohol dehydrogenase

Aspartate aminotransferase, chloroplast

633 precursor

649 flavanone 3-hydroxylase

657 NAD-dependent sorbitol dehydrogenase

712 Chalcone synthase

Chalcone synthase

Chalcone synthase

Chalcone synthase

763 Enolase 1

773 1-aminocyclopropane-1-carboxylic acid oxidase

785 Fructose-bisphosphate aldolase

791 Type IIIa membrane protein cp-wap13

793 Heat shock protein 81-3

801 Heat shock protein 101

825 Adenosine kinase isoform 2T

Granulebound starch synthase 1 chloroplastic

889 amyloplastic

972 Superoxide dismutase

996 Thiosulfate sulfurtransferase $\begin{array}{llll}\text { TC102152 } & 4 & 12.1 & \text { A5HSI } 1\end{array}$

TC87322

$\begin{array}{llll}\text { TC93736 } & 4 & 4.1 & \text { A7PT66 }\end{array}$

TC108803

TC81108

TC84361

TC97755

TC81214

TC94525

TC84952

TC85748

TC93000

TC93671

TC80765

TC81819

TC114376

TC106627

TC108803

TC96791

TC108369

TC96565

TC83788

TC93574
$9.1 \quad \mathrm{P} 51818$

$10.0 \quad \mathrm{Q} 43023$

$10.7 \quad$ Q43022

$\begin{array}{ll}8.2 & \mathrm{P} 46248\end{array}$

11.9 Q5XPX2

14.0 Q9MBD7

8.6 Q8GUU4

15.2 Q2ENC0

16.4 Q2ENB1

14.4 Q9MBF0

5.9 Q9LEJ0

Q84L58

$9.9 \quad$ A7P3F7

$8.0 \quad \mathrm{O} 24548$

$5.0 \quad \mathrm{P} 51818$

4.6 Q6F2Y7

12.0 Q5DKU6

$2 \quad 3.6 \quad \mathrm{Q} 43784$

$2 \quad 5.7$ A5JVZ3

$\begin{array}{lll}4 & 9.2 & \text { Q9ZPK0 }\end{array}$
Bambusa oldhamii

Bambusa oldhamii

Vitis vinifera

Arabidopsis thaliana

Pinus banksiana

Pinus banksiana

Arabidopsis thaliana

Ginkgo biloba

Prunus persica

Pinus pinaster

Picea abies

Abies alba

Pinus densiflora

Hevea brasiliensis

Cicer arietinum

Vitis vinifera

Vigna unguiculata

Arabidopsis thaliana

Oryza sativa

Nicotiana tabacum

Manihot esculenta

Ginkgo biloba

Datisca glomerata

\begin{tabular}{cccc}
63412 & 5.4 & 62918 & 5.6 \\
14993 & 8.2 & & \\
89589 & 5.1 & 46795 & 5.1 \\
80052 & 5.0 & 46923 & 5.0 \\
40460 & 5.7 & 49030 & 5.7 \\
40554 & 5.8 & & \\
& & & \\
49831 & 8.2 & 46380 & 6.1 \\
40410 & 5.6 & 47593 & 5.5 \\
39145 & 6.5 & 47274 & 5.8 \\
43154 & 6.1 & 46221 & 6.1 \\
43264 & 6.2 & & \\
43227 & 6.0 & & \\
43352 & 5.8 & & \\
47830 & 5.6 & 45231 & 6.1 \\
35089 & 5.0 & 44848 & 5.4 \\
42894 & 8.9 & 41464 & 5.7 \\
39422 & 6.2 & 46157 & 5.6 \\
80052 & 5.0 & 45199 & 5.0 \\
100896 & 5.9 & 44624 & 5.4 \\
37524 & 5.2 & 45167 & 5.3 \\
& & & \\
66968 & 8.3 & 52350 & 5.0 \\
25268 & 8.8 & 23585 & 5.2 \\
41382,8 & 6.5 & 39867 & 5.3 \\
\hline
\end{tabular}

Putative proteins more abundant in SE cultured on $8 \mathrm{gL}^{-1}$ gellan gum compared to $4 \mathrm{gL}^{-1}$

\begin{tabular}{|c|c|c|c|c|c|c|c|c|c|c|}
\hline \multirow[t]{2}{*}{$\begin{array}{l}\text { Spot } \\
\text { no. }\end{array}$} & \multirow[t]{2}{*}{ Assignment } & \multirow[t]{2}{*}{$\mathbf{T C}$} & \multirow[t]{2}{*}{$\begin{array}{c}\# \\
\text { pep. }^{c}\end{array}$} & \multirow[t]{2}{*}{$\begin{array}{c}\% \\
\operatorname{cov}^{d}\end{array}$} & \multirow[t]{2}{*}{$\begin{array}{c}\text { Accession } \\
\text { no. }\end{array}$} & \multirow[t]{2}{*}{ Species } & \multicolumn{2}{|c|}{ Theoretical } & \multicolumn{2}{|c|}{ Experimental } \\
\hline & & & & & & & Mr(Da) & pI & $\mathrm{Mr}(\mathrm{Da})$ & pI \\
\hline \multirow[t]{3}{*}{2} & Chalcone synthase & TC82329 & 3 & 9.9 & Q8GUU4 & Pinus pinaster & 43154 & 6.1 & 47306 & 6.0 \\
\hline & Chalcone synthase & TC83662 & 3 & 10.7 & Q9MBF0 & Pinus densiflora & 43352 & 5.8 & & \\
\hline & Chalcone synthase & TC85748 & 4 & 11.0 & Q2ENC0 & Picea abies & 43264 & 6.2 & & \\
\hline
\end{tabular}


Chalcone synthase

88 Ras-related protein Rab2B

166 Heat shock $70 \mathrm{kDa}$ protein

259 Isopentenyl diphosphate isomerase Isopentenyl diphosphate isomerase Isopentenyl diphosphate isomerase

260 Inositol3phosphate synthase 6-phosphogluconate dehydrogenase,

292 decarboxylating

332 Ras related protein Rab11B

367 Glucose regulated protein homolog 4

374 Acyl-CoA binding family protein

375 Proteasome subunit beta type

406 Predicted protein

410 Proteasome subunit beta type 3

Proteasome subunit beta type-3

451 Rasrelated protein RIC1

747 UDP-glucose dehydrogenase

UDP-glucose dehydrogenase

781 Actin7

788 AcetylCoA acetyltransferase cytosolic 2

962 Chromosome chr5 scaffold-67,
995 Uncharacterized protein At2g41620 -3E-61

\begin{tabular}{|c|c|c|c|c|c|c|c|c|}
\hline TC93000 & 4 & 11.9 & Q2ENB1 & Abies alba & 43227 & 6.0 & & \\
\hline ТC90586 & 4 & 24.7 & P49104 & Physcomitrella patens & 23061 & 7.0 & 20808 & 6.1 \\
\hline ТC94610 & 2 & 3.7 & Q96269 & $\begin{array}{l}\text { Arabidopsis thaliana } \\
\text { Nicotiana langsdorffii } \times N \text {. }\end{array}$ & 91618 & 5.1 & 66876 & 5.2 \\
\hline TC108307 & 5 & 9.39 & Q078Z5 & sanderae & 33511 & 6.2 & 31663 & 5.1 \\
\hline TC82458 & 5 & 9.57 & Q1XIS8 & Gentiana lutea & 27216 & 5.0 & & \\
\hline ТC94076 & 5 & 10.34 & Q0QYT2 & a batatas & 33770 & 5.7 & & \\
\hline TC114216 & 5 & 14.1 & Q9FYV1 & n indicum & 56234 & 5.6 & 57427 & 5.8 \\
\hline ТC90774 & 3 & 4.4 & A5BGC9 & Vitis & 53920 & 6.2 & 55671 & 5.8 \\
\hline TC86043 & 2 & 7.5 & Q40521 & Nicotiana tabacum & 24259 & 5.5 & 24256 & 5.6 \\
\hline TC85812 & 3 & 9.3 & Q9AVT8 & Picea abies & 48217 & 4.8 & 39325 & 4.9 \\
\hline TC88346 & 4 & 16.9 & Q10AZ9 & Ory & 58001 & 5.2 & 67738 & 5.4 \\
\hline TC100209 & 6 & 17.3 & A7P520 & ifera & 24915 & 5.3 & 22692 & 5.6 \\
\hline TC81496 & 2 & 3.5 & A9TZW4 & nitrella $p$ & 49946 & 5.8 & 53755 & 6.0 \\
\hline TC87204 & 6 & 37.0 & O65084 & Picea mariana & 22908 & 5.5 & 20329 & 5.5 \\
\hline TC101700 & 4 & 6.5 & O65084 & Picea & 22908 & 5.5 & & \\
\hline TC82990 & 3 & 11.5 & P40392 & $\begin{array}{l}\text { Oryza sativa } \\
\text { Cinnamomum }\end{array}$ & 22476 & 5.2 & 19850 & 5.9 \\
\hline TC111185 & 2 & 5.1 & Q6RK08 & $\begin{array}{l}\text { osmophloeum } \\
\text { Cinnamoтum }\end{array}$ & 47042 & 5.9 & 55160 & 5.9 \\
\hline TC8 & 2 & 8.5 & Q6I & & 52933 & 6.0 & & \\
\hline ТC90279 & 5 & 16.2 & P53495 & $\operatorname{Arc}$ & 41735 & 5.3 & 43571 & 5.6 \\
\hline TC81432 & 6 & 20.5 & Q3E8F1 & Arabidopsis thaliana & 43291 & 6.0 & 42485 & 5.7 \\
\hline TC89652 & 3 & 8.8 & A7Q9M3 & Vitis vinifera & 37542 & 6.1 & 42837 & 5.8 \\
\hline TC87364 & 2 & 10.0 & Q94CF2 & Arabidopsis thaliana & 96615 & 6.7 & 18765 & 5.9 \\
\hline
\end{tabular}

${ }^{a}$ Excised spot number, refers to the spot number labelled in Fig. 4.

${ }^{\mathrm{b}}$ Tentative consensus (TC) given in the DFCI database.

${ }^{\mathrm{c}}$ Number of matching peptides (\# pep.).

${ }^{\mathrm{d}}$ Ratio of the amino acids in detected peptides to total protein amino acids: coverage (\% cov.).

${ }^{\mathrm{e}}$ Accession number of the corresponding protein in the Uniprot database (http://www.uniprot.org/).

${ }^{\mathrm{f}}$ Theoretical molecular mass (Mr) and the isoelectric point $(\mathrm{p} I)$ computed by the ExPASy website (http://www.expasy.ch/). 
Table 2: Distributions of the identified putative proteins among functional classes according to culture conditions.

\begin{tabular}{lccc}
\hline & $\%$ & $4>8$ & $8>4$ \\
\hline Metabolism (26) & $38 \%$ & 19 & 7 \\
carbohydrate metabolism & $41,0 \%$ & 11 & 5 \\
energy metabolism & $5,1 \%$ & 2 & 0 \\
lipid metabolism & $7,7 \%$ & 1 & 2 \\
nucleotide metabolism & $2,6 \%$ & 1 & 0 \\
amino acid metabolism & $15,4 \%$ & 5 & 1 \\
metabolism of other amino acids & $2,6 \%$ & 0 & 1 \\
metabolism of cofactors and vitamins & $2,6 \%$ & 1 & 0 \\
biosynthesis of secondary metabolites & $17,9 \%$ & 4 & 3 \\
xenobiotics biodegradation and metabolism & $5,1 \%$ & 1 & 1 \\
Genetic information processing (16) & $23 \%$ & 11 & 5 \\
Environmental information processing (6) & $9 \%$ & 0 & 6 \\
Cellular processes (16) & $23 \%$ & 10 & 6 \\
Others (5) & $7 \%$ & 3 & 2 \\
\hline
\end{tabular}

For each class, the total number of proteins is indicated in brackets and the corresponding percentage in the first column. Then number of proteins showing higher abundance in one of the culture conditions are listed: $4>8$ : number of proteins with higher abundance in SEs cultivated with $4 \mathrm{gL}^{-1}$ gellan gum; 8>4: number of proteins with higher abundance in SEs cultivated with 8 $\mathrm{gL}^{-1}$ gellan gum. The "Metabolism" class is divided into sub-classes with the corresponding percentage and number of proteins in each subclass presented. Proteins involved in more than one process were assigned to more than one categorical group. Hence the sum of proteins in the categories exceeds the total number of proteins. 


\section{Supporting Information}

Appendix S1: Spots containing more than one putative identified protein, presented according to gellan gum level in the culture medium.

\begin{tabular}{|c|c|c|c|c|c|c|c|c|c|c|}
\hline \multirow{3}{*}{$\begin{array}{l}\text { Spot } \\
\text { no. }\end{array}$} & \multirow{3}{*}{ Assignment } & \multirow{3}{*}{$\mathbf{T C}^{\mathbf{b}}$} & \multirow{3}{*}{$\begin{array}{c}\# \\
\text { pep. }^{\text {c }}\end{array}$} & \multirow{3}{*}{$\operatorname{cov}^{\mathrm{d}}$} & \multirow{3}{*}{$\begin{array}{c}\text { Accession } \\
\text { no. }\end{array}$} & \multirow{3}{*}{ Species } & \multirow{2}{*}{\multicolumn{2}{|c|}{ Theoretical }} & \multirow{2}{*}{\multicolumn{2}{|c|}{ Experimental }} \\
\hline & & & & & & & & & & \\
\hline & & & & & & & Mr(Da) & pI & $\mathrm{Mr}(\mathrm{Da})$ & $\mathbf{p I}$ \\
\hline \multicolumn{11}{|l|}{$4>8^{g}$} \\
\hline \multirow[t]{3}{*}{271} & Actin & TC81626 & 3 & 7.7 & Q9SPI7 & Picea & 41590 & 5.3 & 29683 & 5.4 \\
\hline & RuBisCO binding protein subunit alpha & & & & & & & & & \\
\hline & chloroplastic & TC98306 & 3 & 11.4 & P08823 & Triticum aestivum & 57520 & 4.8 & & \\
\hline \multirow[t]{2}{*}{322} & Enolase 1 & TC80765 & 4 & 13.0 & Q9LEJ0 & Hevea brasiliensis & 47830 & 5.6 & 44561 & 5.5 \\
\hline & ATP synthase subunit beta mitochondrial & TC91214 & 3 & 9.7 & P17614 & Nicotiana plumbaginifolia & 59856 & 6.0 & & \\
\hline \multirow[t]{2}{*}{569} & 3-ketoacyl-CoA thiolase 2 peroxisomal & TC105370 & 4 & 9.4 & Q56WD9 & Arabidopsis thaliana & 48578 & 8.6 & 45869 & 5.5 \\
\hline & Glutamine synthetase nodule isozyme & TC98980 & 3 & 5.5 & P32289 & Vigna aconitifolia & 39104 & 5.7 & & \\
\hline \multicolumn{11}{|c|}{$8>4^{\mathrm{h}}$} \\
\hline \multirow[t]{3}{*}{447} & Endoglucanase 24 & TC109144 & 3 & 7.5 & Q9SVJ2 & Arabidopsis thaliana & 55495 & 5.0 & 20968 & 5.9 \\
\hline & Benzoquinone reductase & TC95089 & 3 & 10.2 & A3F7Q3 & Malvoideae & 21665 & 6.1 & & \\
\hline & Pyrophosphatefructose 6-phosphate 1- & & & & & & & & & \\
\hline \multirow[t]{2}{*}{527} & phosphotransferase & TC101014 & 2 & 4.4 & Q41140 & Ricinus communis & 67360 & 7.6 & 56309 & 5.8 \\
\hline & Glucose1phosphate adenylyltransferase & TC81818 & 2 & 2.8 & P55233 & Beta vulgaris & 57716 & 6.1 & & \\
\hline \multirow[t]{2}{*}{566} & Short-chain dehydrogenase/reductase SDR & TC111316 & 2 & 7.6 & Q2HTL8 & Medicago truncatula & 31804 & 7.0 & 34536 & 5.8 \\
\hline & Pyrophosphate-dependent phosphofructokinase & TC93339 & 2 & 3.6 & Q9ZST3 & Citrus $x$ paradisi & 61696 & 6.1 & & \\
\hline \multirow[t]{2}{*}{576} & Enolase 1 & TC80765 & 6 & 18.6 & Q9LEJ0 & Hevea brasiliensis & 47830 & 5.6 & 53627 & 5.8 \\
\hline & ATP synthase subunit beta mitochondrial & TC91214 & 7 & 21.5 & $\mathrm{P} 17614$ & Nicotiana plumbaginifolia & 59856 & 6.0 & & \\
\hline
\end{tabular}

${ }^{a}$ Excised spot number, refers to the spot number labelled in Figure 4.

${ }^{\mathrm{b}}$ Tentative consensus (TC) given in the DFCI database.

${ }^{\mathrm{c}}$ Number of matching peptides (\# pep.).

${ }^{\mathrm{d}}$ Ratio of the amino acids in detected peptides to total protein amino acids: coverage ( $\%$ cov.).

${ }^{\mathrm{e}}$ Accession number of the corresponding protein in the Uniprot database (http://www.uniprot.org/).

${ }^{\mathrm{f}}$ Theoretical molecular mass $(\mathrm{Mr})$ and the isoelectric point $(\mathrm{p} I)$ computed by the ExPASy website (http://www.expasy.ch/).

${ }^{g}$ Putative proteins more abundant in SE cultured on $4 \mathrm{gL}^{-1}$ gellan gum compared to $8 \mathrm{gL}^{-1}$.

${ }^{\mathrm{h}}$ Putative proteins more abundant in SE cultured on $8 \mathrm{gL}^{-1}$ gellan gum compared to $4 \mathrm{gL}^{-1}$. 
